PLANT METHODS

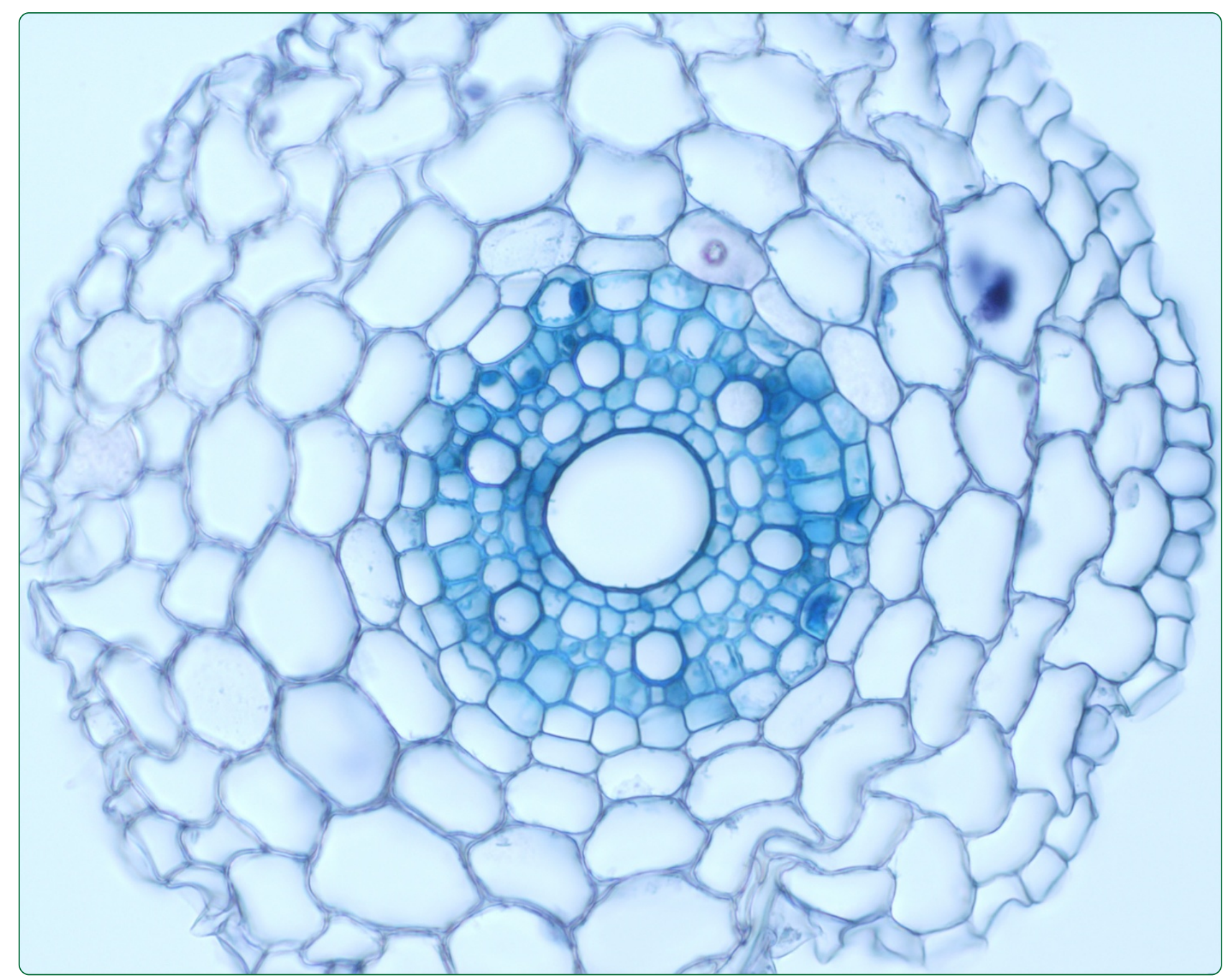

Protocol: a fast and simple in situ PCR method for localising gene expression in plant tissue

Athman et al. 


\title{
Protocol: a fast and simple in situ PCR method for localising gene expression in plant tissue
}

\author{
Asmini Athman ${ }^{1,3+}$, Sandra K Tanz ${ }^{2 \dagger}$, Vanessa M Conn ${ }^{1,3}$, Charlotte Jordans ${ }^{1,3}$, Gwenda M Mayo ${ }^{3,4}$, Weng W Ng ${ }^{1,3}$,
} Rachel A Burton ${ }^{5}$, Simon J Conn ${ }^{3,6}$ and Matthew Gilliham ${ }^{1,3^{*}}$

\begin{abstract}
Background: An important step in characterising the function of a gene is identifying the cells in which it is expressed. Traditional methods to determine this include in situ hybridisation, gene promoter-reporter fusions or cell isolation/purification techniques followed by quantitative PCR. These methods, although frequently used, can have limitations including their time-consuming nature, limited specificity, reliance upon well-annotated promoters, high cost, and the need for specialized equipment. In situ PCR is a relatively simple and rapid method that involves the amplification of specific mRNA directly within plant tissue whilst incorporating labelled nucleotides that are subsequently detected by immunohistochemistry. Another notable advantage of this technique is that it can be used on plants that are not easily genetically transformed.

Results: An optimised workflow for in-tube and on-slide in situ PCR is presented that has been evaluated using multiple plant species and tissue types. The protocol includes optimised methods for: (i) fixing, embedding, and sectioning of plant tissue; (ii) DNase treatment; (iii) in situ RT-PCR with the incorporation of DIG-labelled nucleotides; (iv) signal detection using colourimetric alkaline phosphatase substrates; and (v) mounting and microscopy. We also provide advice on troubleshooting and the limitations of using fluorescence as an alternative detection method. Using our protocol, reliable results can be obtained within two days from harvesting plant material. This method requires limited specialized equipment and can be adopted by any laboratory with a vibratome (vibrating blade microtome), a standard thermocycler, and a microscope. We show that the technique can be used to localise gene expression with cell-specific resolution.

Conclusions: The in situ PCR method presented here is highly sensitive and specific. It reliably identifies the cellular expression pattern of even highly homologous and low abundance transcripts within target tissues, and can be completed within two days of harvesting tissue. As such, it has considerable advantages over other methods, especially in terms of time and cost. We recommend its adoption as the standard laboratory technique of choice for demonstrating the cellular expression pattern of a gene of interest.
\end{abstract}

Keywords: In situ PCR, RT-PCR, Cell-specific localisation, Plant tissue, Immunohistochemistry

\section{Introduction}

The function of only a small fraction of genes from any species has been experimentally verified. For the majority of plant genes, their function are either unknown or have been predicted through homology with a known

\footnotetext{
* Correspondence: matthew.gilliham@adelaide.edu.au

${ }^{\dagger}$ Equal contributors

'ARC Centre of Excellence in Plant Energy Biology, University of Adelaide, Glen Osmond, SA, Australia

${ }^{3}$ Waite Research Institute \& School of Agriculture, Food and Wine, University of Adelaide, PMB1, Glen Osmond, SA 5064, Australia

Full list of author information is available at the end of the article
}

gene from another species [1]. With the advent of next generation sequencing, this disparity between annotated genes and those that are functionally characterized is likely to increase.

An important step toward understanding the role of a gene product is to identify the tissue and cell type within which it is expressed. However, transcript abundance is predominantly analysed using whole plants or organs. Despite the fact that few transcripts are expressed exclusively within a single cell type, many genes are preferentially expressed in only a few cell types [2]. Analysing the transcript abundance of such genes in whole plants or 
organs may be misleading and will reflect the net expression for those particular genes in all cells rather than in the cell types in which they are actually expressed. This is of particular relevance for genes expressed predominantly in cell types that comprise only a small percentage of the total analysed tissue. Even if transcripts of genes of interest are highly abundant in one or few cell types the total number of the transcripts of interest may be diluted to below the detection limits within the whole tissue RNA pool. Such a phenomenon is not uncommon as there are a number of specific cell-types that appear to have a profound influence on the performance of the plant and act as 'gatekeepers' for a particular physiological process $[3,4]$. These cell-types contain proteins and signalling cascades that are primed for a particular physiological role so have unique transcriptional profiles. Such cell-types include, but are not limited to, guard cells (that undergo large turgor changes to control whole plant gas exchange), xylem parenchyma (which control net xylem content so have a major influence on long-distance nutrient and water transport), and pericycle (which initiate lateral root development so have a major role in root architecture). The transcriptional profiling of whole tissues can therefore be extremely misleading when ascribing a function to a gene and caution should be observed when interpreting expression data from tissue samples containing more than one cell-type. Awareness of such issues has led to the development of techniques that have allowed researchers to examine the expression of specific genes in specific cell types.

Common assays for detecting where transcripts are expressed can be classified in several ways (Table 1). Ordinarily they rely on one of the following: 1 ) the generation of transgenic plants with indicator proteins or nucleic acid/ribosomal binding proteins; 2) the isolation of single cells or single cell contents; 3 ) the hybridisation of RNA/cDNA directly in tissue; or 4) a combination of 1 and 2. These techniques can be classified into two further groups: A) those that first isolate RNA from a tissue or specific cell-type and then identify a transcript of interest in that RNA pool or, B) those that search directly for the transcript of interest in living or fixed plant tissue. We have summarised the advantages and disadvantages of these methodologies in Table 1.

Many of these methods have long lead times as they require the generation of transgenic plants so in these instances can be unsuitable for species that cannot be transformed or for the analysis of multiple genes. Also,

Table 1 Techniques available for in planta cell level expression analysis

\begin{tabular}{llll}
\hline Technique & Type & Comments & References \\
\hline $\begin{array}{l}\text { Specific gene promoter: indicator } \\
\text { protein fusions [i.e. beta-glucuronidase } \\
\text { (GUS) or fluorescent proteins] }\end{array}$ & 1, B & $\begin{array}{l}\text { Long lead times of }>2 \text { months to get stably expressed genes, homozygous } \\
\text { gene expression, sequences other than the promoter may control gene } \\
\text { expression, no guarantee that promoter fragment chosen is correct, not } \\
\text { suitable for plants that cannot be transformed. }\end{array}$ & [5]
\end{tabular}

Laser Capture Microdissection (LCM) and Single Cell Sampling (SiCSA) in situ PCR

2, A Difficulty in isolating certain cell-types (e.g. vascular cells using SiCSA), long tissue prep ( 2 weeks) for LCM, need for specialised equipment

3, B No specialised equipment required apart from vibratome, simple and fast method. No detailed protocol for plants until this manuscript, especially for agarose- embedded vibratome- sectioned in tube PCR. Can be performed on plants that are difficult to, or cannot be transformed. We do not recommend fluorescence detection of in situ PCR products due to interference with autofluorescence from plant tissue. As it is possible to do separate PCRs on adjoining tissue sections or replicate tissues from other plants we see no great advantage in multiplexing in situ PCR as it causes multiple complications to what is a robust and relatively simple technique. We do not recommend multiplexing in situ PCR due to the differential abundance of transcripts in the same cell and consequently the saturation of products, generation of non-specific products and problems with signal separation.

High detection threshold (10-20 copies per cell for ISH vs 1-2 copies per cell for in situ PCR), need to design a specific probe that hybridises to RNA while in situ PCR uses the same primers as qPCR, much cheaper. The View RNA Assay (Affymetrix) enables automated multiple transcript detection using fluorescence by employing the principles of ISH to detect nucleic acid targets within specific cells/cell-types. Its use is limited to abundant transcripts and laboratories equipped with and/or experienced in FFPE (formalin-fixed paraffin embedded) and frozen tissue preparation.

Protoplasting of fluorescently labelled cells and single cell sorting (FACS)

Can assay multiple transcripts at the same time. Potential damage responses of tissue. Needs specialised sorting flow cytometer. Limited to analysis of cells that are fluorescently labelled. Cannot give detail of all cells in which a particular gene is expressed.

Nuclear sorting, INTACT (isolation of nuclei tagged in specific cell types) or ribosomal binding techniques

In situ RNA sequencing

4, A When combined with microarrays or RNAseq can assay multiple transcripts at the same time. Limited to analysis of cells that are fluorescently labelled. Cannot give detail of all cells in which a particular gene is expressed. Not easily replicated.

3, B Offers the prospect of obtaining whole transcriptomes and more from single cells in tissue sections. Not yet optimised in any tissue. Has not been performed for plant tissue. 
many of these methods are difficult to adopt in a laboratory not set up for such techniques without a significant outlay as they utilize expensive and specialized equipment and expertise. Of the non-transgenic techniques, in situ hybridization and in situ PCR are methods that allow gene expression analysis at a single cell resolution. Two disadvantages of in situ hybridization revolve around sensitivity. Firstly, low-copy mRNAs often result in a false negative signal and secondly, highly homologous members of the same gene family are difficult to distinguish. Both of these issues are addressed with in situ PCR because a specific region of the gene transcript is amplified during multiple cycles of the PCR resulting in a highly sensitive technique.

In situ PCR is a semi-quantitative method that has been used to detect target RNA using colourimetry or fluorescence. Therefore it is useful to detect in which cell types genes are expressed. To precisely quantitate transcript levels in tissues or single cells, in situ PCR should be used in conjunction with a quantitative transcript detection technique (such as Single cell sampling and analysis (SiCSA) in combination with RNASeq, qPCR, or microarrays (Table 1).

In situ PCR has been described and performed extensively in animals and a detailed protocol has been made available [15]. Reports of in situ PCR on plant material either include lengthy tissue preparations, thermal cycling of slide-mounted specimens, or a detailed protocol was not supplied [16-20]. Here, we have further developed the in situ PCR technique, allowing improved resolution of transcript localisation. We also include detailed recommendations for the implementation of this technique in a variety of plant tissues to improve its utility (Figure 1). This includes both an in-tube protocol, which uses a standard thermocycler block for routine samples and an on-slide methodology, which uses a slide thermal cycler for use with fragile tissues. Although this alternative is not necessary for most applications of in situ PCR, it has advantages for very thin sections $(<15 \mu \mathrm{m})$, or for delicate dissected tissues such as epidermal peels. We have used this method in published articles for the localisation of transcripts in wheat, barley and soybean [21-24], but due to the constraints of most journals have not had the opportunity to publish the methodology in the detail required for others to follow. Here, to outline the technique we include a full protocol and we show the preferential localisation of transcripts in various plant tissues and cell types, including guard cells, mesophyll, xylem parenchyma, pericycle, and different reproductive tissues.

\section{Protocol}

\section{Overview}

To preserve the morphology of the plant tissue and to anchor the transcripts to their cellular origin, freshly harvested plant tissue is immediately fixed in an ethanol/ acetic acid/formaldehyde solution with the penetration of the fixative enhanced through vacuum infiltration (Figure 1). The plant tissue is then embedded in agarose for subsequent sectioning on a vibratome (Figure 1). Sections are collected into a microfuge tube or placed on a slide. DNase treatment, reverse transcription and in situ PCR can all be carried out in the microfuge tube using a standard thermal cycler or on the slide using an in situ block. DNase treatment is carried out to remove genomic DNA (Figure 1), which would otherwise lead to erroneous detection of signal. The DNase-treated RNA in the tissue is converted to cDNA by reverse transcription (Figure 1). The resulting cDNA is amplified by standard gene-specific PCR integrating Digoxigenin (DIG) labeled nucleotides (Figure 1). The sections are incubated with an anti-DIG antibody conjugated to alkaline phosphatase, which binds to the DIG-labeled PCR products (Figure 1). Adding specific substrates for alkaline phosphatase allows the colourimetric detection of the DIG-labeled PCR products, delimited to the site of RNA synthesis. At this point, if the protocol was carried out in a microfuge tube, the sections are transferred onto a microscope slide (Figure 1). After mounting the slides, the processed tissue sections can be visualized by bright field microscopy (Figure 2).

\section{Plant growth and tissue sampling}

The protocol described here concentrates on the amplification of RNA/cDNA from leaf and root tissues across a range of plant species (Table 2). By optimizing various aspects of the conditions, this method can be adapted easily to tissue types other than leaf or root (Table 2). The plant-growth method is inconsequential for the success of this technique, but we recommend hydroponics for root tissue samples to simplify harvesting of tissue [25]. Roots of plants grown in soil or agar should be immersed repeatedly in sterile water using a soft paintbrush to remove particulate matter while minimising damage to the roots.

Prior to performing in situ PCR, it is important to consider the time of day that the tissue will be harvested, the growth stage of the plant, and the tissue type, as these factors may influence gene expression. As a general rule, we sampled at relative midday with respect to the photoperiod. For leaves, we use young and undamaged leaves, harvesting material with the midrib intact as this provides extra stability to the sections. Excising the leaf tip, outer margins and base ( $>2 \mathrm{~mm}$ from petiole) simplifies vibratome sectioning, handling and visualization of sections. We generally avoid older root sections with a large number of lateral root hairs as the root hairs tend to stick to the blade during vibratome sectioning, and this may result in whole root samples being pulled out of the agarose block. The time taken to prepare the material for fixation 


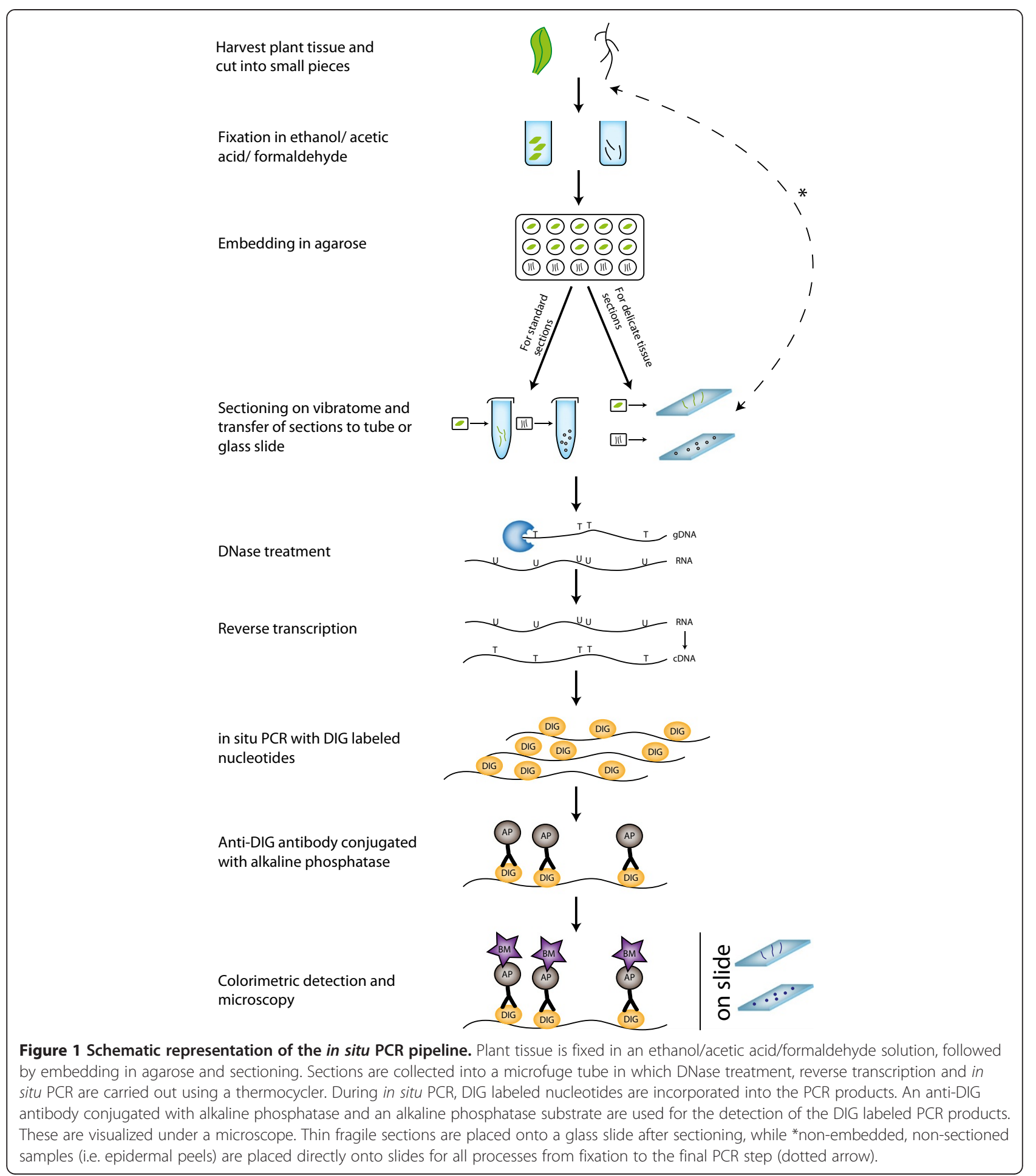

should be kept to a minimum as RNA may begin to degrade and tissue begins to wilt. In our experience we can prepare tissue in under 1 minute. This will not avoid very rapid changes in expression caused by handling; such changes are unavoidable in most applications. The number of leaves or roots to be harvested depends on the number of transcripts to be tested by in situ RTPCR, with at least 3 reproducible biological replicates per tissue per condition being required to confirm expression patterns - this means that more than three tissue replicates will need to be harvested and fixed to account for damage or loss of tissue etc. 

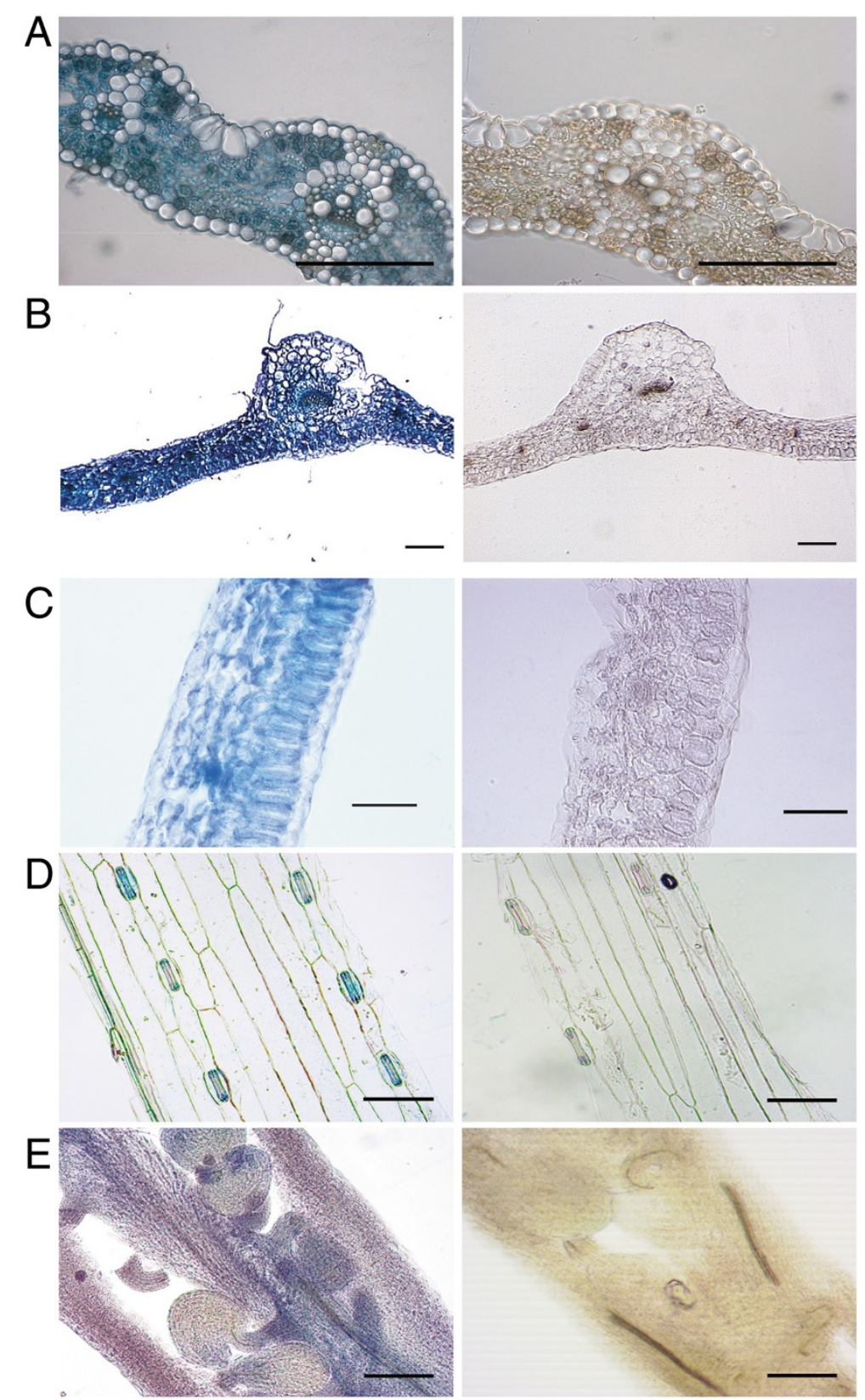

$\mathrm{F}$

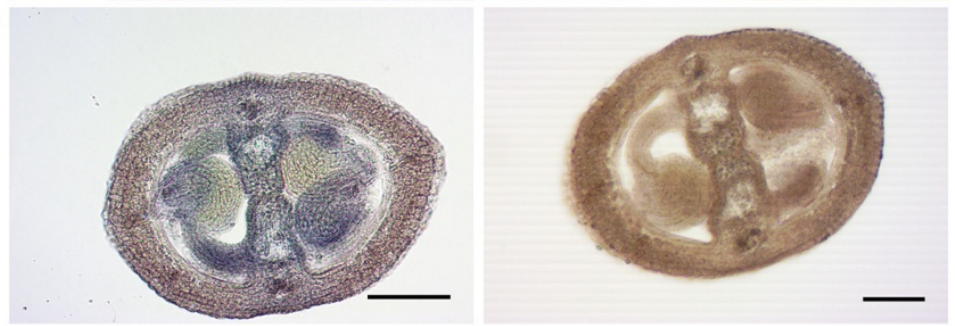

Figure 2 In situ PCR for various transcripts in barley and Arabidopsis. Blue staining demonstrates presence of cDNA (left panel) while a brown colour indicates absence of amplified target CDNA within cells (right panel). (A, left) 185 ribosomal RNA positive control to show staining in all cell-types of barley leaf, (B, left) 185 ribosomal RNA positive control to show staining in all cell-types of Arabidopsis leaf, (C, left) AtCAX1 expression predominantly in the mesophyll of Arabidopsis leaf, (D, left) guard cell staining of a barley Aluminum-activated malate transporter (ALMT) (SL1251) from an in situ PCR performed on epidermal peels. (E and F, left) detection of an Arabidopsis ALMT14 in the septum (E) and embryo (F) of developing flowers/siliques. The same primers and conditions were used for the corresponding negative controls (A-F, right panels, Table 6). Scale bars represent $100 \mu \mathrm{m}$. 
Table 2 Various alkaline phosphatase (AP) substrates used with this in situ PCR protocol on different plant species and tissues

\begin{tabular}{|c|c|c|}
\hline Plant species & Tissue & AP substrate \\
\hline \multirow[t]{3}{*}{ Arabidopsis thaliana } & \multirow[t]{3}{*}{ Leaf } & BM Purple \\
\hline & & Elf97 \\
\hline & & Vector Blue \\
\hline Arabidopsis thaliana & Flower & BM Purple \\
\hline Cleome gynandra & Leaf & BM purple \\
\hline Cleome hassleriana & Leaf & BM purple \\
\hline Glycine max & Root & BM purple \\
\hline \multirow[t]{2}{*}{ Hordeum vulgare } & \multirow[t]{2}{*}{ Leaf } & BM purple \\
\hline & & Elf97 \\
\hline \multirow[t]{2}{*}{ Hordeum vulgare } & \multirow[t]{2}{*}{ Epidermal peel } & BM Purple \\
\hline & & $\mathrm{Elf9}^{++}$ \\
\hline \multirow[t]{2}{*}{ Oryza sativa } & \multirow[t]{2}{*}{ Leaf } & BM Purple \\
\hline & & Vector Blue \\
\hline Oryza sativa & Root & BM Purple \\
\hline Solanum lycopersicum & Leaf & Vector Blue \\
\hline Triticum aestivum & Root & BM Purple \\
\hline Triticum durum & Leaf & Elf97 \\
\hline \multirow[t]{3}{*}{ Triticum durum } & \multirow[t]{3}{*}{ Root } & BM Purple \\
\hline & & NBT/BCIP ${ }^{X}$ \\
\hline & & Vector Blue ${ }^{++}$ \\
\hline Vitis vinifera & Root & Vector Blue \\
\hline Vitis vinifera & Leaf & BM Purple \\
\hline Zea mays & Leaf & BM Purple \\
\hline
\end{tabular}

Most AP substrates were used successfully for specific detection of the transcript in question, with some exceptions as indicated. ${ }^{++}$indicates detection with significant background staining. ${ }$ indicates no detectable signal.

\section{Tissue preparation}

The method of tissue preparation used in this protocol involves formaldehyde/acetic acid/ethanol fixation and agarose-embedding, a fast and simple method that preserves the morphology of the plant tissue and keeps the RNA molecules intact [26]. Formaldehyde is a small and highly permeable molecule [27], which accurately preserves cellular morphology, condensing fixation times of most samples to two hours. It is reported that fixation in excess of four hours for leaves and 12 hours for roots in formaldehyde can result in excessive cross-linking of proteins to nucleic acids [28,29], which can interfere with the subsequent reverse transcription resulting in no detectable staining or in significant background staining of the sample.

Following fixation, the tissue should be embedded in molten agarose and allowed to cool for at least 1.5 hours prior to sectioning. This is significantly shorter than the time required for paraffin embedding (2-7 days). The RNA in the agarose-embedded tissue is stable for at least three weeks and can be detected on plant tissue sections cut as thin as $20 \mu \mathrm{m}$ using a vibratome. Better image clarity is observed with thinner sections but these are more easily damaged than thicker sections during the wash steps. We recommend $50 \mu \mathrm{m}$ thick sections for roots and $60-70 \mu \mathrm{m}$ sections for leaves. While the sections may not be as thin as those that can be cut from frozen or paraffin-embedded tissues $(4-15 \mu \mathrm{m})$, cell morphology is well preserved and transcripts are easily detected following in situ PCR in tissue sections of up to $75 \mu \mathrm{m}$ thick. Furthermore, the absence of the pre- and post-treatment steps that are required with paraffin embedding and cryosectioning, make agarose embedding a technique suitable for any standard laboratory without the need for specialized equipment.

Generally, we embed three leaf samples or eight root samples per agarose block. The sectioning of one of these agarose blocks should yield enough tissue sections to perform in situ PCRs on at least three transcripts. From our experience, to be confident in the localisation of a transcript we suggest that at least ten tissue sections are visualised per transcript per biological replicate to check that the expression patterns are consistent across tissues in at least three biological replicates. To account for loss or damage to samples during processing we recommend starting with three times the amount of sections during vibratome sectioning and at least one additional biological replicate (so examine tissues from four plants). During sectioning the tissue usually separates from the agarose, so the number of sections can be counted onto the slide or tube for processing.

In some cases (such as with epidermal peels or the seed aleurone), tissue can be dissected from the plant without the need for sectioning on a vibratome. The processing of these non-embedded tissues should be carried out entirely on glass slides from fixation through to the final PCR and staining steps. In addition, if thin $(<50 \mu \mathrm{m})$ or particularly fragile sections are needed for PCR, then it is again best to avoid in-tube processing of these samples; instead, these tissues are best processed on slides. To do this, when sections are taken postfixation and embedding, they should be collected directly onto the slide for the DNAse treatment step and through to the final PCR and staining steps. These variations in the sample processing are highlighted in the protocol below.

\section{Primer design}

Primers should be designed to the cDNA sequence of a plant species. To test if the primer sequences align to genomic DNA (gDNA), the primer sequence can be compared against available gDNA sequences using BLAST (http://blast.ncbi.nlm.nih.gov/). The primers should amplify a 150-300 bp product, since this size product simplifies 
amplification within the cellular matrix and provides sufficient DIG incorporation (and thus signal) per amplicon. Oligonucleotides should be $18-24$ bases long, have an annealing temperature of $55^{\circ} \mathrm{C}$ and if possible, span an exon-exon junction to prevent the amplification of gDNA. If the latter is not possible, the primers should be designed to span an intron sequence (i.e. the two primers are on two different exons) so that possible amplification from gDNA is eliminated by using a short extension time during the in situ PCR. The following standard primer design features should also be observed: they should amplify a single product; contain no internal secondary structure (hairpin, palindromes, selfdimers, repeats and runs in excess of four bases); contain 40-60\% G/C; and, should not be self-complementary to avoid primer dimer formation. To assist with these guidelines, free online primer design and primer analysis tools can be used, such as Primer3 (http://simgene. com/Primer3) and NetPrimer (http://www.premierbiosoft. com/netprimer/).

\section{Optimization of PCR conditions}

Before conducting in situ PCR on any plant tissue, the amplification conditions must be optimised in solution, such as the concentration of magnesium and dNTPs, the type of polymerase used, the annealing temperature, extension time and cycle number. Optimised parameters invariably transfer successfully to the in situ PCR protocol. To determine the number of cycles that should be used for the in situ PCR, it is critical to choose the minimum cycle number that gives an identifiable product to maximise the chance of differentiating abundance between cell types, albeit semi-quantitatively, for the gene of interest. The cycle number used for in situ PCRs may be different for each gene to be tested. When choosing a cycle number for the in situ PCR, it needs to be considered that the PCRs are not likely to be as efficient for cDNA contained within plant tissue as compared to cDNA in solution, and the incorporation of DIG-dUTP during the in situ PCR may have an inhibitory effect on the DNA polymerase. Considering the above points, adding 1-2 cycles to the cycle number obtained from the in-solution PCR is recommended when conducting the in situ PCR.

\section{RT-PCR}

Since in situ PCR is primarily used for detecting a particular mRNA, an in situ reverse transcription (RT) step precedes the in situ PCR. During the RT, mRNAs are converted to cDNAs, either by a random primed or a specific primed RT reaction. Random primed RT reactions use random hexamers that are six bases long and convert all RNA molecules (mRNAs, rRNA and ncRNAs) into cDNA. We generally use the specific primed $\mathrm{RT}$ reaction, where a specific primer designed to the 3 ' end of the transcript of interest is used to reverse transcribe only the required transcript from the mRNA. A fragment of this transcript is then amplified in the following PCR using either a pair of nested gene-specific primers or the RTprimer plus a gene-specific primer $5^{\prime}$ of this. For the design of the RT primer, the standard primer design guidelines apply as described above under 'Primer design'.

\section{Amplicon labeling and detection}

Amplicons can be labeled directly with a fluorescent label, which allows their subsequent detection by microscopy, or indirectly using either digoxigenin (DIG) or biotin. DIG-labeled PCR products can be detected using enzyme-based colour detection systems such as alkalinephosphatase (AP) or peroxidase, using an anti-DIG-enzyme conjugate that binds to the DIG label on the amplicon. Biotin-labeled amplicons can be recognized using a streptavidin-enzyme conjugate for colourimetric detection in a similar fashion. We had most success with the colourimetric detection of an anti-DIG-AP conjugate that recognizes DIG-labeled-dUTP incorporated into the amplicon during the in situ PCR. We have tested different AP substrates with varying success for different plant tissues and species (Table 2). This table includes fluorescent substrates but we found these problematic due to significant detection of autofluorescence from the tissue interfering with our substrate fluorescence (see Results and discussion).

\section{Validation and controls}

To validate the expression pattern of a gene, we routinely perform in situ PCR on replicate tissues from four different plants. In addition, as mentioned above, multiple technical replicates $(\sim 10)$ are useful per biological replicate to validate the site of amplification and detection. A negative control that tests for the presence of contaminating gDNA should be included alongside each transcript analyzed by in situ PCR. This consists of tissue samples, prepared as for the test samples but with the omission of the reverse transcriptase enzyme during the RT step. A positive control should also be included for each tissue sample tested. This should be a gene that is uniformly expressed in all cells; if the effect of a treatment is being tested in your experiment, this gene should remain stably expressed across different treatments. The ribosomal $18 \mathrm{~S}$ transcript, which is expressed across the majority of plant species and is ubiquitously expressed in all cells, is recommended.

\section{Materials \\ Reagents}

- RNase Zap (Sigma, cat. no. R2020).

- Fixative (see REAGENT SETUP). 
- Ethanol (Chem-supply, cat no. 64-17-5, 100\% Analytical Reagent).

- Acetic acid (Southern Cross Science, cat no. AA009-2.5LP).

- Formaldehyde (Sigma, cat. no. 252549-4 L).

- Wash Buffer 1 (see REAGENT SETUP).

- $1 \times$ PBS (see REAGENT SETUP).

- Agarose (Bioline, cat. no. BIO-41025) (see REAGENT SETUP).

- Ultra-low gelling temperature agarose (Sigma, cat. no. A2576) (see REAGENT SETUP).

- $1 \mathrm{~L}$ sterile water (ice-cold).

- $40 \mathrm{U} \mu \mathrm{L}^{-} 1$ RNaseOUT (Invitrogen, cat. no. 10777019).

- 10x Turbo DNA-free Buffer from Turbo DNA-free kit (Ambion, cat. no. AM1907). Only use the buffer TURBO DNaseI did not work well on plant sections.

- RNase-Free DNase Set (1500 U, lyophilised; Qiagen, cat. no. 79254) (see REAGENT SETUP).

- 0.5 mM EDTA, pH 8.0 (Chem-Supply, cat no. 6381-92-6) (see REAGENT SETUP).

- dNTPs (10 mM each; Bioline, cat. no. BIO-39025).

- Thermoscript RT kit (Invitrogen, cat. no. 11146-024).

- RT reaction solution (see REAGENT SETUP).

- HiFiPhusion polymerase (Thermo Scientific, $2 \mathrm{U} \mu \mathrm{L}^{-1}$, cat. no. F-530S).

- Digoxigenin-11-dUTP, alkali stable (DIG-11-dUTP, $1 \mathrm{mM}$; Roche, cat. no. 11093088910).

- Gene-specific forward and reverse primers.

- PCR reaction solution (see REAGENT SETUP).

- $1 \times$ Block solution (see REAGENT SETUP).

- Anti-Digoxigenin-AP, Fab fragments (Anti-DIG antibody; Roche, cat. no. 11093274910) (see REAGENT SETUP).

- Wash Buffer 2 (see REAGENT SETUP).

- AP substrates: BM Purple AP Substrate (Roche, cat. no. 11442074001) or Vector Blue Substrate Kit (Abacus ALS, cat. no. VESK5300) or NBT-BCIP solution (Sigma-Aldrich, cat. no 72091) or ELF97 Endogenous Phosphatase Detection Kit (Life Technologies, cat. no. E-6601).

- 40\% glycerol (VWR, cat. no. 24397.296) (see REAGENT SETUP).

- Clear nail varnish.

\section{Equipment}

- Micro scissors (Wescott spring scissors; Proscitech, cat. no. TS1084).

- Soft paintbrushes

- Tweezers (ProSciTech, cat no. T045-212).

- Sterile scalpel (ProSciTech, cat.no. METP2325-10-CE).

- Sterile $150 \mathrm{~mm}$ petri dishes (Sarstedt, cat.no. 82.1184.001).
- $2 \mathrm{~mL}$ microfuge tubes (VWR, cat. no. 211-2120).

- Vacuum infiltrator (EYELA Aspirator, cat. no. A-3S).

- 3 MM Whatmann filter paper (diameter $90 \mathrm{~mm}$; VWR, cat. no. WHAT1001-090). Sterilize by autoclaving.

- Sterile 12-well plates (Adelab, cat. no. CNG3513).

- 0.2 mL PCR tubes (Adelab, cat. no. AXYPCR-02-C).

- Vibratome Leica VT1200 with magnetic specimen plate, buffer tray and ice bath (see EQUIPMENT SETUP).

- Superglue (Selleys Quick Fix).

- Double-edge blade (ProSciTech, cat. no. L056).

- Single-edge blade (ProSciTech, cat. no. L055C).

- Thermal cycler (Geneworks, cat. no. GS00001).

- In-situ block (Geneworks, cat. no. GSBOSITU).

- Microscope slides (ProSciTech, cat. no. G300B) or StarfrostSilane-prep slides (Sigma, cat. no. S4651-72EA).

- Frame-seal slide chambers (BioRad, cat. no. SLF0601).

- Coverslips (ProSciTech, cat.no. GCC2222).

- Glass pipette.

- For brightfield imaging: Leica, AS LMD microscope.

- For fluorescence detection: Zeiss Axiophot microscope: DAPI, BP 365/12, FT 395, LP 397.

- OR, Nikon A1R laser scanning confocal microscope: UV excitation using DAPI laser line (405 nm ex).

\section{Reagent setup}

Fixative $63 \%$ Ethanol, 5\% acetic acid, 2\% formaldehyde. Prepare fresh and use within $3 \mathrm{~h}$. Keep on ice.

\section{Caution}

Hazardous chemicals should be handled in a fume cupboard using appropriate personal protective equipment.

Wash Buffer 1 63\% Ethanol, 5\% glacial acetic acid. Prepare fresh and keep on ice.

\section{Caution}

Hazardous chemicals should be handled in a fume hood using appropriate personal protective equipment

10× PBS stock solution, pH 7.5 0.1 $\mathrm{M} \mathrm{Na}_{2} \mathrm{HPO}_{4}, 1.3 \mathrm{M}$ $\mathrm{NaCl}, \mathrm{pH}$ 7.5. Dissolve $14.19 \mathrm{~g} \mathrm{Na}_{2} \mathrm{HPO}_{4}$ in $800 \mathrm{~mL}$ of sterile water. Adjust to $\mathrm{pH} 7.5$ by adding $37 \% \mathrm{HCL}$. Add $75.9 \mathrm{~g}$ of $\mathrm{NaCl}$ and add sterile water to a total volume of $1 \mathrm{~L}$. This solution can be kept for 1 year at room temperature.

$1 \times$ PBS, pH 7.5 Dilute the stock $10 \times$ PBS at 1:10 ratio to give a final concentration of $0.01 \mathrm{M} \mathrm{Na}_{2} \mathrm{HPO}_{4}$ and $0.13 \mathrm{M} \mathrm{NaCl}$. This solution can be kept up for 1 year at room temperature.

5\% Agarose or 5\% Ultra-low gelling agarose Dissolve 2.5 Agarose (leaves) or ultra-low gelling agarose (roots) in $50 \mathrm{~mL} 1 \times$ PBS. Can be kept at $4^{\circ} \mathrm{C}$ for 6 months.

\section{Critical step}

Ultra-low gelling agarose is recommended for embedding root tissue, while regular agarose works best on leaves. On the day of use, melt the agarose by heating in a 
water bath in a microwave oven under medium power and keep in a water bath/incubator at a temperature higher than the gelling temperature. We incubate at $50^{\circ} \mathrm{C}$ for $5 \%$ regular agarose and $37^{\circ} \mathrm{C}$ for $5 \%$ ultra-low gelling agarose.

RNase-Free DNase Set (lyophilised) Add $1.5 \mathrm{~mL}$ of RNase-free water (from kit) to lyophilized DNase I to

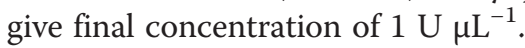

\section{Critical step}

Buffer of this kit is optimized for on-column DNA digestion; do not use it. It is recommend to use 10× Turbo DNA-free Buffer from Turbo DNA-free kit (Ambion) (see REAGENTS).

$0.5 \mathrm{mM}$ EDTA, pH 8.0 Add $18.6 \mathrm{~g}$ EDTA to $\sim 80 \mathrm{~mL}$ of water. Adjust $\mathrm{pH}$ to 8.0 with $\mathrm{NaOH}$. The disodium salt of EDTA will not go into solution until the pH is approximately 8.0. Add water to a total volume of $100 \mathrm{~mL}$ and sterilize by autoclaving.

RT reaction solution Use Thermoscript RT kit (see REAGENTS) and make up the first master mix according to the manufacturer's instructions and the number of reactions. This initial master mix will contain reverse primer, dNTPs, water and tissue sections. An aliquot of the second master mix (Table 3) is added to the tube or slide containing the first master mix after denaturation of the first master mix.

PCR reaction solution Use HiFi Phusion polymerase kit (see REAGENTS) and make up a master mix on ice according to the number of reactions (Table 4).

10× Block stock solution Mix $10 \mathrm{mg}$ BSA in $1 \mathrm{~mL}$ 10x PBS. May be stored at $-20^{\circ} \mathrm{C}$ for 1 year.

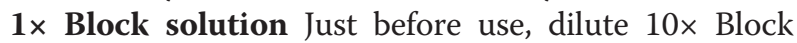
stock solution 1:10 with sterile water to give $1 \times$ Block solution with a final concentration of $1 \%$ BSA in $1 \times$ PBS.

\section{Critical step}

Ensure you make enough $1 \times$ Block solution for blocking step and dilution of the Anti-DIG antibody. Need approximately $150 \mu \mathrm{L} 1 \times$ Block solution per sample.

Anti-Digoxigenin-AP Fab fragment This is the AntiDIG antibody conjugated with alkaline phosphatase (AP). Dilute Anti-DIG-AP Fab fragments 1:500 using 1× Block solution. For 10 samples prepare $550 \mu \mathrm{L}$ : dilute $1.1 \mu \mathrm{L}$ Anti-DIG-AP in $548.9 \mu \mathrm{L} 1 \times$ Block.

Table $3 \mathbf{R T}$ reaction solution

\begin{tabular}{|c|c|c|c|c|}
\hline Component & $\begin{array}{l}\text { Stock } \\
\text { conc. }\end{array}$ & $\begin{array}{l}\text { Final conc./ } \\
\text { amount }\end{array}$ & $\begin{array}{l}1 \times \\
(\mu L, \text { in-tube })\end{array}$ & $\begin{array}{l}1 \times \\
(\mu \mathrm{L}, \text { on-slide })\end{array}$ \\
\hline $\begin{array}{l}\text { cDNA synthesis } \\
\text { buffer (kit) }\end{array}$ & $5 x$ & $1 \times$ & 4 & 20 \\
\hline DTT (kit) & $0.1 \mathrm{M}$ & $5 \mathrm{mM}$ & 1 & 5 \\
\hline RNaseOUT (kit) & $40 \cup \mu \mathrm{L}^{-1}$ & $40 \mathrm{U}$ & 1 & 1 \\
\hline $\begin{array}{l}\text { Thermoscript } \\
\text { RT (kit) }\end{array}$ & $15 \mathrm{U} \mathrm{LL}^{-1}$ & $15 U$ & 1 & 1 \\
\hline
\end{tabular}

Table 4 PCR reaction solution

\begin{tabular}{|c|c|c|c|c|}
\hline Component & Stock conc. & $\begin{array}{l}\text { Final conc./ } \\
\text { amount }\end{array}$ & $\begin{array}{l}1 \times \\
(\mu \mathrm{L}, \text { in-tube) }\end{array}$ & $\begin{array}{l}1 \times \\
(\mu \mathrm{L}, \text { on-slide) }\end{array}$ \\
\hline $\begin{array}{l}\text { HiFi Phusion } \\
\text { buffer }\end{array}$ & $5 x$ & $1 \times$ & 10 & 20 \\
\hline dNTPs & $10 \mathrm{mM}$ & $0.2 \mathrm{mM}$ & 1 & 2 \\
\hline DIG-11-dUTP & $1 \mathrm{mM}$ & $4 \mu \mathrm{M}$ & 0.2 & 0.4 \\
\hline $\begin{array}{l}\text { HiFi Phusion } \\
\text { polymerase }\end{array}$ & $2 \cup \mu \mathrm{L}^{-1}$ & $1 U$ & 0.5 & 0.5 \\
\hline Sterile water & & & 33.3 & 67.1 \\
\hline
\end{tabular}

Wash Buffer $20.1 \mathrm{M}$ Tris-Cl, $0.15 \mathrm{M} \mathrm{NaCl}, \mathrm{pH} 9.5$. Can be kept at $4^{\circ} \mathrm{C}$ for 1 year.

40\% glycerol Dilute $4 \mathrm{~mL}$ of $100 \%$ glycerol with water to give a final volume of $10 \mathrm{~mL}$.

\section{Equipment setup}

Vibratome setup The Leica VT1200 vibrating microtome comes with a magnetic specimen plate, buffer tray and ice bath. Assemble the vibratome according to the manufacturer's instructions. Add sterile ice-cold water to the buffer tray. The water provides a flotation medium for the sections. To maintain the cold temperature, fill the integrated ice bath with crushed ice.

Frame-seal slide chambers If performing the in-situ PCR directly on slides the frame-seal should be adhered to the slide following the manufacturer's instructions. Label all slides with species, gene name, whether negative or positive control, and the date.

Thermal cyclers If performing in-tube PCR, any standard thermal cycler is suitable. If performing reactions on slides, a thermal cycler with a block that can hold slides is necessary (see EQUIPMENT).

\section{Procedure \\ Critical step}

General guidelines for working with RNA apply to avoid contamination with RNases. All solutions need to be RNase-free. Clean all surfaces and utensils with Ethanol and RNase Zap (see Reagents) or equivalent. Use filter tips or new sterile tips for RNA work only.

\section{Sample preparation and fixation}

Timing $\sim 3.5$ h (leaves), 20 h (roots), $\sim 1.5 h$ (non-embedded, non-sectioned samples)

1 Prepare fixative fresh and before harvesting plant material (see REAGENT SETUP). Place on ice.

\section{Caution}

Hazardous chemicals should be handled in a fume hood, and using appropriate personal protective equipment.

For non-embedded, non-sectioned samples: If the material to be tested is less than $50 \mu \mathrm{m}$ thick (i.e. only 1-2 cell layers as for epidermal peels or aleurone layers), 
the agarose embedding and vibratome sectioning steps (Figure 1) are omitted from the protocol. All processes from fixation through to in situ PCR and staining are performed directly on a microscope slide.

2 Aliquot $1.8 \mathrm{~mL}$ fresh fixative into $2 \mathrm{~mL}$ microfuge tubes ( 1 per species and tissue) and place on ice.

For non-embedded, non-sectioned samples: Aliquot $100 \mu \mathrm{L}$ fresh fixative onto the rectangular frame seal slide chamber on a glass slide and keep on a cold flat surface.

3 Harvest plant tissue using micro-scissors and place onto a sterile surface (i.e. petri dish). Using a sterile scalpel, cut leaves into $3 \times 5 \mathrm{~mm}$ pieces and roots $5 \mathrm{~mm}$ long making sure each cut is perpendicular to the long axis of the tissue. For 10 in situ PCRs it is recommended to prepare 12 leaf pieces (4 agarose blocks with 3 samples each) and 32 root pieces (4 agarose blocks with 8 samples each).

For non-embedded, non-sectioned samples: The samples are placed directly onto the glass slides containing the fixative and incubated three times for $15 \mathrm{~min}$ on a cold flat surface, changing the fixative every time. Proceed to step 7 (washes).

\section{Critical step}

Samples should be limited in size to a maximum of $5 \mathrm{~mm}$ in width or length, as the fixative can only penetrate up to $5 \mathrm{~mm}$ through the tissue. Include the middle vein in leaf pieces as this assists in maintaining the integrity of the leaf sections during the procedure.

4. Using a soft paintbrush, transfer leaf or root pieces immediately into $1.8 \mathrm{~mL}$ ice-cold fixative in $2 \mathrm{~mL}$ tubes. Carefully invert tubes three times and ensure samples are fully submerged and move unrestricted. This is done to ensure fixative is saturating and can easily access all surfaces of the samples. If the samples do not float freely, transfer some of the samples to a second tube with cold, fresh fixative.

\section{Critical step}

The time between harvesting the plant tissue and submerging it in fixative should be as short as possible.

5 Vacuum infiltrate $(400 \mathrm{~mm} \mathrm{Hg})$ twice for $1.5 \mathrm{~min}$ (2 mL tubes open lid). Between infiltrations, cap tubes and gently mix samples.

6 Incubate leaf samples for 3-4 h in fixative on ice. Incubate roots for at least $12 \mathrm{~h}$ in fixative in the dark at $4^{\circ} \mathrm{C}$. For leaf samples only: During the 3-4 h incubation time change the fixative every hour taking care not to damage the tissue. Keep tubes on ice in fume hood.

\section{Washes}

\section{Timing $1 \mathrm{~h}$}

7 Wash three times for $10 \mathrm{~min}$ in $1.8 \mathrm{~mL}$ of ice-cold Wash Buffer 1 (see REAGENT SETUP). After last wash, remove as much of the wash buffer as possible.
For non-embedded, non-sectioned samples: Use $100 \mu \mathrm{L}$ of Wash Buffer 1.

8 Wash three times for $3 \mathrm{~min}$ in $1.8 \mathrm{~mL}$ of ice-cold $1 \mathrm{x}$ PBS (see REAGENT SETUP). After last wash, remove $600 \mu \mathrm{L}$ of PBS and discard.

For non-embedded, non-sectioned samples: Wash three times in $100 \mu \mathrm{L}$ of $1 \times \mathrm{PBS}$, add $85 \mu \mathrm{L}$ sterile water and $2.5 \mu \mathrm{L}$ of $40 \mathrm{U}^{-1}$ RNaseOUT (=100 U) (see REAGENT SETUP) to each slide to give a final volume of $87.5 \mu \mathrm{L}$ then proceed directly to step 29 (DNase treatment).

\section{Embedding \\ Timing $\sim 1 h$}

9 Place three sterile 3MM Whatman filter papers into the lid of a round petri dish (1 per sample).

Steps 10 and 11, process one sample at a time:

10 Invert contents of a $2 \mathrm{~mL}$ tube over the filter paper in the petri dish lid. Use a soft paintbrush to gently transfer any remaining samples onto filter paper.

11 In a sterile 12-well plate, half-fill a well with the molten 5\% agarose (leaves) or ultra-low gelling agarose (roots) (see REAGENT SETUP). Immediately transfer tissue pieces into the molten agarose using a soft paintbrush. Ensure tissue pieces are fully submerged in the agarose. After orienting the tissue pieces, place 12-well plate on ice for agarose to solidify.

\section{Critical step}

Leaves: Place three leaf pieces in each well. Using two paintbrushes, orient the leaf pieces with flat faces parallel to each other and each epidermis perpendicular to the bottom of the plate (so the leaf pieces are stacked like the leaves of a book). Repeat at least four times in four different wells.

Roots: On filter paper, gently roll 8 root pieces parallel to each other to form a tight bundle. Using two paintbrushes or gloved hands transfer one bundle (8 root pieces) into an agarose-filled well, orienting the long axis (epidermis) perpendicular to the bottom of the plate. Repeat at least four times in four different wells.

12 Seal plates using parafilm to prevent agarose drying out and store samples at $4{ }^{\circ} \mathrm{C}$ for at least $3 \mathrm{~h}$ prior to sectioning to ensure the agarose is solidified thoroughly for sectioning on a vibratome. RNA should remain stable for at least three weeks.

PAUSE POINT.

\section{Sectioning}

Timing $\sim 3.5 h$

For thin fragile sections: If sections thinner than $50 \mu \mathrm{m}$ are desired from agarose embedded samples, we recommend proceeding on silanised glass slides [15] from this point to minimise tissue disturbance. Tissue sections are held in place between glass slide and plastic seal of frame- 
sealed chambers preventing the sections from coming in contact with the pipette tip, which would otherwise cause tissue damage.

13 Prepare $0.2 \mathrm{~mL}$ PCR tubes and keep on ice during vibratome sectioning ( 1 tube per transcript to be tested, including controls):

For both non-embedded, non-sectioned samples AND thin fragile sections: Prepare frame-seal chambers on silane glass slides [15] and pipette water and RNaseOUT onto the slides according to 'leaf tissue' volumes below.

For leaf tissue, add $85 \mu \mathrm{L}$ sterile water and $2.5 \mu \mathrm{L}$ of 40 $\mathrm{U} \mu \mathrm{L}^{-1}$ RNaseOUT (=100 U) (see REAGENT SETUP) to each tube to give a final volume of $87.5 \mu \mathrm{L}$. Leaf sections will be placed into this solution.

For root tissue, add $5 \mu \mathrm{L}$ sterile water and $2.5 \mu \mathrm{L}$ of 40 $\mathrm{U} \mu \mathrm{L}^{-1}$ RNaseOUT (=100 U) (see REAGENT SETUP) to each tube. Four times $20 \mu \mathrm{L}$ sterile water containing root sections will be added to this solution to give a final volume of $87.5 \mu \mathrm{L}$.

14 Using a sterile scalpel, cut a square agarose block from a well in the 12-well plate, taking care not to cut the embedded tissue. Remove agarose edges. Use tweezers to lift the square agarose block onto a sterile petri dish. Alternatively, flip the 12-well plate upside down and then place the block on a petri dish. Using a sterile scalpel cut off excess agarose closer to the tissue to reduce the size of the block, taking care not to cut the embedded tissue.

15 Place superglue onto the magnetic vibratome specimen plate slightly off centre (so agarose block can be orientated later). The amount should be enough to cover the base of the block. Immediately place agarose block onto superglue using tweezers or gloved hands.

16 Place the specimen plate into its buffer tray, cover the tray with its lid and place on ice for at least $5 \mathrm{~min}$ for the superglue to dry.

17 Fill the buffer tray with ice-cold sterile water until the agarose block is just covered. The cooled water provides a flotation medium for the sections.

18 Place the buffer tray into the ice bath and fill the ice bath with crushed ice to maintain the cold temperature of the water.

19 Assemble ice bath/buffer tray/specimen plate onto vibratome.

20 Place a double-edge blade into the holder, tighten and turn into position for sectioning. The blade should sit just above the agarose block and be in contact with the water.

21 If required, orient the agarose block by turning the specimen plate. Section leaves lengthwise along the leaf. This helps to keep the leaf sections intact and prevents leaf pieces to be pulled out of the agarose block.

22 Before setting section thickness for cutting (raising the stage), move the blade back until $\sim 0.5 \mathrm{~cm}$ behind the agarose block. Set thickness of sections for preliminary trimming at $\sim 200 \mu \mathrm{m}$ to cut away any excess agarose until the tissue is reached. Set velocity $\left(0.4 \mathrm{~mm} \mathrm{sec}^{-1}\right)$ and amplitude $(0.4 \mathrm{~mm})$.

23 Press 'Run' to cut section and again to stop. Remember to reverse blade before raising stage for next cut.

24 Once the blade is in contact with the tissue, continue sectioning at $60-70 \mu \mathrm{m}$ (leaves) or $50 \mu \mathrm{m}$ (roots). Repeat 6-7 times. These first few sections will be damaged from processing and can be discarded. Collect the sections from the next 3 cuttings onto a microscope slide.

\section{Critical step}

Generally, the sections will split from the agarose and float into the cold water. Use a soft paintbrush to collect leaf sections onto the glass slide. To collect root sections use a $200 \mu \mathrm{L}$ micropipettor with a cut-off tip and pipette water with root sections onto the glass slide.

25 Check the integrity of the collected sections under a bright field microscope (using $4 \times, 10 \times$ and $20 \times$ objectives). If the sections look 'blurred', the tissue is not cut at a perpendicular angle and the adjustable stage needs to be tilted/rotated in order to correct the orientation of the block, ensuring the long axis of the tissue is perpendicular to the blade.

26 If the sections are intact and appear 'in focus', start collecting fresh sections into $0.2 \mathrm{~mL}$ PCR tubes containing sterile water with $100 \mathrm{U}$ RNaseOUT (prepared at step 13). Keep tubes on ice.

For thin fragile sections: Sections are transferred to the silane glass slide with water and RNaseOUT (prepared at step 13). Keep the glass slide on a cold, dry surface.

\section{Critical step}

Leaves: Use a soft paintbrush to collect at least 15 leaf sections into each PCR tube containing sterile water and $100 \mathrm{U}$ RNaseOUT $(87.5 \mu \mathrm{L})$. This takes about $30-45 \mathrm{~min}$ per tube. Take care to collect sections to the tip of the paintbrush, as it can be difficult to remove sections from the paintbrush after transfer. If sections are not separating fully from the agarose, gently tease away the agarose using a paintbrush or tweezers.

Roots: Collect root sections using a $200 \mu \mathrm{L}$ pipette with a cut-off tip, pipette up water with root sections from buffer tray and transfer into an empty tube. Once roots settle to the bottom of the tube, remove excess water until $20 \mu \mathrm{L}$ remains in the tube. Alternatively, remove all water and add $20 \mu \mathrm{L}$ water to the tube. Transfer $20 \mu \mathrm{L}$ of water with root sections into PCR tubes containing sterile water and $100 \mathrm{U}$ RNaseOUT. Repeat this process four times in total to collect at least 35 root sections in a final volume of $87.5 \mu \mathrm{L}$.

If multiple transcripts are to be tested, the collection of sections should be done concurrently rather than consecutively to ensure sections across different in situ PCRs are similarly sized and are from the same region of 
the tissue (i.e. collect sections from the first cut into PCR tube 1, sections from the second cut into PCR tube 2 , etc.). This is important as leaf and root morphology and possibly expression of genes may vary along the tissue.

Take care to frequently change the blade or the section of the blade that is cutting the tissue, because the cut from a blunt blade tends to be jagged and uneven.

If root sections do not separate from ultra-low gelling temperature agarose after cutting, transfer them into a tube with sterile water using a paintbrush. Heat at $65^{\circ} \mathrm{C}$ for $10 \mathrm{~min}$ to melt the agarose. Wash three times with sterile $65^{\circ} \mathrm{C}$ warm water before proceeding.

27 Once enough sections have been collected, disassemble the ice bath/buffer tray/specimen plate from the vibratome. Cut around the bottom of the agarose block using a single-edge blade, before slicing underneath the block to lift it off the specimen plate. If there is a substantial amount of plant material left in the block, use tweezers or paintbrushes to transfer the agarose block back into the 12-well plate. Viable tissue samples can be kept at $4^{\circ} \mathrm{C}$ for at least three weeks.

28 Clean the superglue from the specimen plate by carefully scraping a single-edge blade over it, taking care not to damage the specimen plate.

\section{DNase treatment}

\section{Timing $\sim 1 \mathrm{~h}$}

\section{Critical step}

Take great care when pipetting solutions into and out of $0.2 \mathrm{~mL}$ PCR tubes or from the glass slide containing the sections. They are very easily damaged and may stick to the pipette tip. Gently pipette up and down to mix the sample and if this not possible, flick tubes using finger. Do not use a centrifuge. Sections should never be allowed to dry; prepare mastermixes for next step during the current incubation such that as soon as solution 1 is removed, solution 2 can be added.

29 On ice, to the $0.2 \mathrm{~mL}$ PCR tubes containing $87.5 \mu \mathrm{L}$ sterile water, RNaseOUT and tissue sections, add $10 \mu \mathrm{L}$ of $10 \times$ Turbo DNA-free buffer (Ambion) and $2.5 \mu \mathrm{L}$ of $1 \mathrm{U} \mu \mathrm{L}^{-1}$ DNase I (Qiagen) (see REAGENT SETUP) to give a final volume of $100 \mu \mathrm{L}$.

For both non-embedded, non-sectioned samples AND thin fragile sections: Add the above DNase reaction mixture directly onto the tissue samples on the glass slide containing water and RNaseOUT.

30 Incubate at $37^{\circ} \mathrm{C}$ for $45 \mathrm{~min}$ in a thermocycler with either a $0.2 \mathrm{ml}$ PCR tube block or a slide block.

31 Add $3.3 \mu \mathrm{L}$ of $0.5 \mathrm{M}$ EDTA, pH 8.0 (see REAGENT SETUP) to give a final concentration of $15 \mathrm{mM}$. Heat inactivate the DNase I enzyme at $70^{\circ} \mathrm{C}$ for $15 \mathrm{~min}$. Place on ice.

Critical step

For non-embedded, non-sectioned samples AND thin fragile sections: In our experience the glass slide is prone to cracking due to expansion and contraction of the metal PCR block. To avoid this we recommend removing the slides prior to the final cooling step. For instance, if the thermal cycler is set to cool down to $4^{\circ} \mathrm{C}$ after the $70^{\circ} \mathrm{C}$ EDTA incubation in the DNase step, remove the slide in the final 5 seconds of the $70^{\circ} \mathrm{C}$ incubation and place on a cold $\left(4^{\circ} \mathrm{C}\right)$ flat surface. This also applies to subsequent incubations (see steps 37 and 39).

32 Using a $200 \mu \mathrm{L}$ pipette, carefully remove the DNase solution and discard.

33 Wash twice for $1 \mathrm{~min}$ in $150-200 \mu \mathrm{L}$ ice-cold sterile water.

34 Using a $200 \mu \mathrm{L}$ pipette and $10 \mu \mathrm{L}$ pipette gently remove as much of the water as possible.

\section{Reverse transcription}

Timing $\sim 1.5 h$

\section{Critical step}

For the negative controls, add all reagents except Thermoscript RT. Alternatively exclude negative controls from the RT and keep samples at $4^{\circ} \mathrm{C}$ in $1 \times \mathrm{PBS}$ during steps $35-39$.

$35 \mathrm{On}$ ice, to each $0.2 \mathrm{~mL}$ PCR tube containing the sections, add $10 \mu \mathrm{L}$ of sterile water and $2 \mu \mathrm{L}$ of $10 \mathrm{mM}$ dNTPs.

For non-embedded, non-sectioned samples AND thin fragile sections: Add $60.5 \mu \mathrm{L}$ of sterile water and $10 \mu \mathrm{L}$ of $10 \mathrm{mM}$ dNTPs.

36 Add $1 \mu \mathrm{L}$ of $10 \mu \mathrm{M}$ gene-specific reverse primer.

For non-embedded, non-sectioned samples AND thin fragile sections: Add $2.5 \mu \mathrm{L}$ of $10 \mu \mathrm{M}$ gene-specific reverse primer.

\section{Critical step}

Reverse primers that have previously been used in qPCR generally work well as primer in RT and in the subsequent in situ PCR. Alternatively, design a new reverse primer that is $5^{\prime}$ of the gene-specific reverse primer used in the in situ PCR (see "Primer design" and "RT-PCR" for more details).

37 In a thermal cycler, incubate samples for $5 \mathrm{~min}$ at $65^{\circ} \mathrm{C}$ and hold at $4^{\circ} \mathrm{C}$ for at least $1 \mathrm{~min}$. Place on ice.

For non-embedded, non-sectioned samples AND thin fragile sections: See critical note under step 31.

38 Add $7 \mu \mathrm{L}$ of RT reaction solution (see REAGENT SETUP, Table 3).

For non-embedded, non-sectioned samples AND thin fragile sections: Add $27 \mu \mathrm{L}$ of RT reaction solution.

$39 \mathrm{In}$ a thermal cycler, incubate for $1 \mathrm{~h}$ at $50^{\circ} \mathrm{C}, 5 \mathrm{~min}$ at $85^{\circ} \mathrm{C}$, and then hold at $4{ }^{\circ} \mathrm{C}$.

For non-embedded, non-sectioned samples AND thin fragile sections: See critical note under step 31.

PAUSE POINT. 


\section{In situ PCR}

\section{Timing 1-2.5 $h$}

40 Place tubes/glass slides into a rack on ice. Using a $200 \mu \mathrm{L}$ pipette carefully remove the RT solution.

41 Wash twice for $1 \mathrm{~min}$ in 150-200 $\mu \mathrm{L}$ ice-cold sterile water.

42 Using a $200 \mu \mathrm{L}$ and $10 \mu \mathrm{L}$ pipette remove as much of the water as possible.

$43 \mathrm{On}$ ice, to each $0.2 \mathrm{~mL}$ PCR tube containing the sections add $45 \mu \mathrm{L}$ of PCR reaction solution (see REAGENT SETUP).

For non-embedded, non-sectioned samples AND thin fragile sections: Add $90 \mu \mathrm{L}$ of PCR reaction solution.

44 Add $2.5 \mu \mathrm{L}$ of each $10 \mu \mathrm{M}$ gene-specific forward and reverse primers to give final reaction volume of $50 \mu \mathrm{L}$.

For non-embedded, non-sectioned samples AND thin fragile sections: Add $5 \mu \mathrm{L}$ of each $10 \mu \mathrm{M}$ reverse and forward primers to give a final reaction volume of $100 \mu \mathrm{L}$.

45 Cycling conditions will vary according to primer Tm, product size, and the abundance of the transcript of interest. A sample protocol is given below for primers designed with an annealing temperature of $55^{\circ} \mathrm{C}$ and a product size of approximately $200 \mathrm{bp}$.

Initial denaturation:

$98^{\circ} \mathrm{C} 30^{\prime \prime}$

Cycling. Repeat 20-35× (depending on results from the Test PCR):

$98^{\circ} \mathrm{C} 10^{\prime \prime}$

$55^{\circ} \mathrm{C} 25^{\prime \prime}$

$72^{\circ} \mathrm{C} 5^{\prime \prime}$

Final elongation:

$72^{\circ} \mathrm{C} 7^{\prime}$

$10^{\circ} \mathrm{C}$ hold

For non-embedded, non-sectioned samples AND thin fragile sections: See critical note under step 31.

\section{Colourimetric detection of DIG labeled PCR products Timing $\sim 3-4 h$}

For non-embedded, non-sectioned samples AND thin fragile sections: For on-slide in situ PCR, remove the frame-seal chamber from the slide completely using a scalpel and complete all remaining steps on the slide. During incubations, place the slides within a small and sealable plastic box to minimize evaporation.

46 Place $0.2 \mathrm{~mL}$ PCR tubes into a rack on ice. Using a $10 \mu \mathrm{L}$ pipette, carefully pipette off the rest of the PCR solution.

47 Wash tissue sections twice for $5 \mathrm{~min}$ in 150$200 \mu \mathrm{L} 1 \times$ PBS (see REAGENT SETUP).

48 Using a $200 \mu \mathrm{L}$ and $10 \mu \mathrm{L}$ pipette remove as much of the $1 \times$ PBS as possible.

49 Gently add $100 \mu \mathrm{L}$ of $1 \times$ Block solution (see REAGENT SETUP) to the sections and incubate for $30 \mathrm{~min}$ on ice.
50 During incubation, dilute Anti-DIG-AP antibody 1:500 in 1× Block solution (see REAGENT SETUP). Keep on ice.

51 Using a $200 \mu \mathrm{L}$ pipette and $10 \mu \mathrm{L}$ pipette, carefully pipette off as much of the $1 \times$ Block solution as possible.

52 Add $50 \mu \mathrm{L}$ of diluted Anti-DIG-AP antibody to the tissue sections and incubate at room temperature for $1 \mathrm{~h}$.

53 Using a $200 \mu \mathrm{L}$ pipette, remove the antibody solution.

54 Wash tissue sections twice for $15 \mathrm{~min}$ at room temperature in Wash Buffer 2. Keep sections in Wash Buffer 2 after second wash.

55 For detection move to a Bright Field microscope equipped with a camera.

56 Label silanised microscope slides. Label should include species, gene name, whether negative or positive control, and the date.

57 Using a glass pipette big enough to pipette leaf sections or a $200 \mu \mathrm{L}$ pipette with cut-off tip for root sections, transfer the sections along with Wash Buffer 2 onto a silanised microscope slide. A paintbrush should be used if any sections stick to the wall of the tube.

58 Using a $200 \mu \mathrm{L}$ pipette, remove any excess Wash Buffer from the slide.

\section{Critical step}

Hold pipette tip perpendicularly to the slide surface and remove liquid very slowly.

59 Add $50 \mu \mathrm{L}$ BM purple or any substrate for the AP enzyme to each sample on the glass slides. Some substrates, such as BM purple are light sensitive. Only take an aliquot from the stock and keep in the dark and on ice. Once added to the slides, cover the slides to protect from light and let develop in the dark until a purpleblue signal appears.

60 Initially incubate for $10 \mathrm{~min}$ at room temperature. Check staining under the microscope $(4 \times$ and $10 \times$ objectives, without cover slide) every 15-30 min. Keep slides in the dark.

\section{Critical step}

The time of staining may vary anywhere from $10 \mathrm{~min}$ to over $2 \mathrm{~h}$ depending on species, the abundance of the transcript, and the PCR efficiency. If no signal is detected after $1 \mathrm{~h}$, pipette off the AP substrate and add fresh $50 \mu \mathrm{L}$ BM purple. Do not leave sections to develop overnight, as they will become saturated.

\section{Mounting and microscopy \\ Timing $30 \mathrm{~min}$}

61 Once the stain has developed and the DIG-labeled PCR products are detected, use a $200 \mu \mathrm{L}$ pipette remove the AP substrate from the slide.

62 Add $100 \mu \mathrm{L}$ Wash Buffer 2 and wash three times $5 \mathrm{~min}$ to remove residual stain and any debris.

63 Wash once with $100 \mu \mathrm{L}$ sterile water. Using a $200 \mu \mathrm{L}$ pipette, remove all the water. 
64 Using a $200 \mu \mathrm{L}$ pipette, mount sections in 40-150 $\mu \mathrm{L}$ of $40 \%$ glycerol. The amount of glycerol will depend on the number of sections on your slide. Take care all the sections are covered but do not use an excessive amount of glycerol.

65 Place coverslip on top and seal corners with nail varnish. If the amount of glycerol is too much, such that the coverslip floats, pipette off some glycerol then seal.

\section{Critical step}

Do not place the coverslip by sliding down from one edge (as usually practiced), as all the sections will float to one side. Simply drop the coverslip from above.

66 Sections may be visualized under a bright field or fluorescence microscope for the next 3 weeks. Store slides at room temperature.

\section{Timing overview}

Steps 1-6, fixation: $1 \mathrm{~h}$ procedure plus $2.5 \mathrm{~h}$ incubation (leaves) or $19 \mathrm{~h}$ incubation (roots).

Steps $7+8$, washes: $1 \mathrm{~h}$.

Steps 9-12, embedding: $1 \mathrm{~h}$ procedure plus minimum $3 \mathrm{~h}$ incubation or overnight.

Steps 13-28, sectioning: $3.5 \mathrm{~h}$.

Steps 29-34, DNase treatment: $\sim 1 \mathrm{~h}$.

Steps 35-39, reverse transcription: $\sim 30 \mathrm{~min}$ procedure plus $1 \mathrm{~h}$ incubation.

Steps 40-45, in situ PCR: up to $2.5 \mathrm{~h}$.

Steps 46-60, detection of DIG labeled PCR products: up to $4 \mathrm{~h}$.

Steps 61-66, mounting: $30 \mathrm{~min}$.

\section{Troubleshooting}

Advice on troubleshooting is listed in Table 5.

\section{Results and discussion}

We use in situ PCR as a core technique for gene functional characterisation studies. All the evidence we have gathered so far suggests that it reliably localises the target transcript to the cell-types in which it is expressed. We see distinct patterns of staining when examining the localisation of different transcripts, and these are consistent across technical and biological replicates, and when available, with the results of published studies for the same gene using different transcript localization techniques. For instance, in Figure 2A, B and $3 \mathrm{C}$ using the primers listed in Table 6, we detect the presence of $18 \mathrm{~S}$ ribosomal RNA in all cells, as would be expected. We have previously seen the preferential expression of AtCAX1 in the mesophyll using single cell sampling and laser capture microdissection $[6,7,30]$ and we show the same using in situ PCR (Figure 2C). Figure 3 shows the localisation of a transcript that encodes a sodium transporter in near isogenic lines (NIL) of Triticum durum (durum wheat) cultivar Tamaroi [21]. The near isogenic lines of durum wheat were made after introgression of a genomic fragment from Triticum monococcum in Triticum durum by conventional crossing and backcrossing with the durum wheat parent [21]. The + Nax2 NIL contains Triticum monococcum TmHKT1;5-A (Figure 3B) whereas the - Nax2 NIL lacks TmHKT1;5-A (Figure 3B). Homologues of this gene are expressed in the stele of bread wheat [24], rice [31], Arabidopsis [32] and other plants [33], and we see a very similar expression pattern in durum wheat (Figure 3B). Here, we also present examples of using in situ PCR on delicate tissues for two genes encoding putative organic acid transporters. One is present in the guard cells in epidermal peels from barley leaves (Figure 2D), a common localization for this gene family [34-36] and the other localizes to the septum and embryo of Arabidopsis flower/siliques (Figure 2E and 2F).

Unfortunately, as with every PCR based technique, the experiment may sometimes fail for an unforeseen (and seemingly inexplicable reason), but, in our hands, the vast majority of experiments have yielded usable results, and if care is taken then it will consistently work. However, in the course of optimizing this technique we have encountered several examples of what may go wrong this includes a total absence of detectible transcript, over-staining, and even erroneous detection of transcript (see also Table 5 for troubleshooting tips). Incomplete fixation of RNA and clearing of tissue can result in detection of the target transcripts in fewer cells than in which it is actually expressed. This is exemplified by the lack of detection of $18 \mathrm{~S}$ RNA in all cell types either through poor penetration of fixative (Figure 4A) or poor clearing of chlorophyll (Figure 4B). This is the reason why it is essential to detect a 'house-keeping' transcript, which is equally expressed in all cell-types, at the same time as your target transcript to make sure you have complete and equal fixation and clearing. Performing sectioning on very delicate tissues, including older root tissues, is difficult as they can often fall apart during processing (Figure 4C) so these types of samples are best processed on slides. Figure 4D shows an example of what can happen if the primers detect genomic DNA; the nucleus stains and shows a pattern quite distinctive from cytoplasmic cDNA staining. This scenario can be avoided by optimal primer design.

We attempted to use fluorescence detection of gene expression in tissue sections as we hypothesized we would achieve an improvement over what is possible with colourimetric detection in terms of signal intensity and contrast with the background image. However, due to the inherent autofluorescence in our no RT control sections (of chlorophyll in leaf tissue, and vascular and cuticular regions in leaf and root tissue control samples (Figure $4 \mathrm{E}-\mathrm{H})$ ) the use of fluorescence was less satisfactory as a detection method for gene expression in our 


\section{Table 5 Troubleshooting suggestions}

\section{Step Problem}

Inconsistent staining in the positive control sample (as in Figure 4A and B)

ii) Over-fixation

iii) Under-fixation (tissue may be too large for fixative to penetrate).

11, 20 Poor morphology (as in Figure 4C)

i) Long axis of sample is not perpendicular to blade on vibratome

ii) Sections have been damaged during processing

Nuclear staining throughout the sample (as in Figure 4D)

Amplification of gDNA

45, 60 Staining of sections appears very dark Saturated staining

60 Positive result in the negative "no RT" Background staining caused by presence of control or weak non-specific staining endogenous alkaline phosphatase enzymes in the positive control

\section{Solution}

i) Reduce the time between harvesting plant tissue and placing it in fixative. Follow general rules for working with RNA to prevent contamination with RNases (see also start of protocol).

ii) Reduce overall fixation time, but increase pressure/time of vacuum infiltration to ensure fixative penetrates.

iii) Pieces must be kept at a maximum of $5 \times 5 \mathrm{~mm}$ to ensure fixative can penetrate entire tissue. Increase pressure/time of vacuum infiltration to ensure fixative penetrates.

i) Be quick when orienting the tissue pieces in the molten agarose and place the sample on ice for the agarose to solidify. Examine the first few sections cut on the vibratome and if they appear smeared, adjust the orientation of the block by either tilting the adjustable stage or removing the agarose block and making sure the side stuck on the stage is perfectly flat.

ii) Be careful not to damage the tissue sections during processing (use a paintbrush for manipulation, do not vortex or centrifuge tubes, prevent pipette tip from contacting sections during multiple rounds of pipetting, consider performing experiments on-slide).

Design primers that are split across an exon-exon junction to eliminate the possibility of amplifying gDNA. Alternatively, design primers that have 1 or more large introns between them such that reducing the elongation time during PCR only allows amplification of the smaller CDNA product.

Increase the incubation time of the DNase treatment or change the DNase enzyme.

Reduce the number of cycles in the PCR and/or reduce the overall staining time.

Add levamisole to the substrate to inhibit endogenous alkaline phosphatases. 


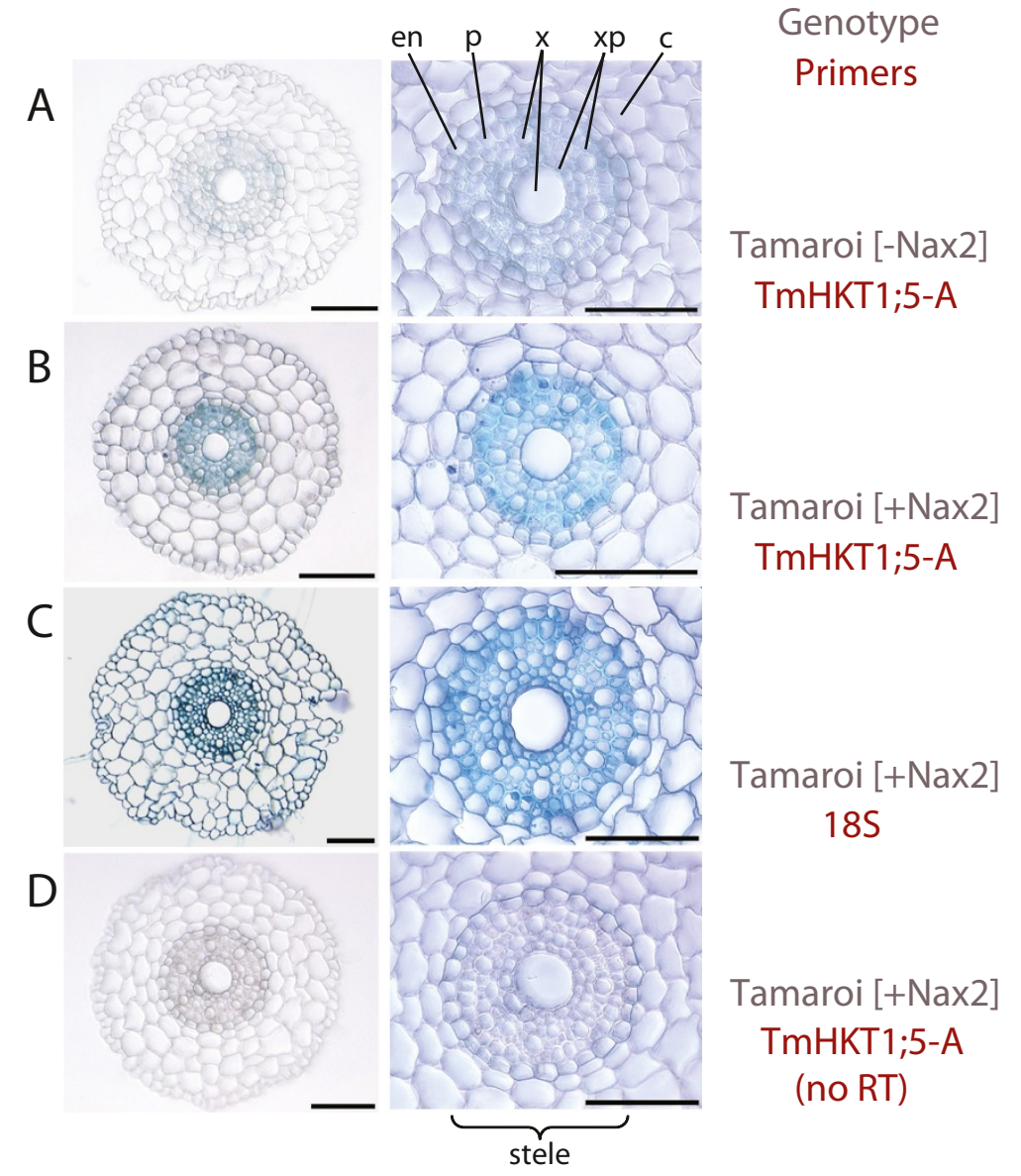

Figure 3 In situ PCR demonstrating vasculature-specific expression of a sodium transporter (TmHKT1;5-A) in durum wheat (Triticum durum) root sections. The blue stain indicates the presence of transcripts while the images in the right panel are magnifications of figures in the left panel. (A) shows that TmHKT1;5-A is undetectable in Tamaroi [-Nax2] (the near-isogenic line without Nax2/TmHKT1;5-A). (B) depicts the stele-specific expression of TmHKT1;5-A in Tamaroi [+Nax2]. In (C) the expression of 185 ribosomal RNA is seen in all cell-types (positive control). (D) is the negative control where the reverse transcription (RT) step was omitted in Tamaroi [+Nax2]. c, cortex; en, endodermis; p, pericycle; x, xylem; xp, xylem parenchyma. Scale bars represent $100 \mu \mathrm{m}$. This figure was originally published in [21].

Table 6 List of primers used during in situ PCR

\begin{tabular}{|c|c|c|}
\hline Gene name & Accession number & Primer sequence $\left(5^{\prime}\right.$ to $\left.3^{\prime}\right)$ \\
\hline \multirow[t]{2}{*}{ HV18S } & AK251731.1 & qF: GGTAATTCCAGCTCCAAT \\
\hline & & qR: GTTATGGTTGAGACTAG \\
\hline \multirow[t]{2}{*}{ TmHKT1; 5-A } & DQ646339.2 & qF: GACCACAAAAGGATAACAAGCA \\
\hline & & qR: AGAACATGACAGCAATGAGAGC \\
\hline \multirow[t]{2}{*}{ GmPIP1; $2 b$} & XM_003532769.2 & qF: TGTIITTGTATGTGCTTGCTTG \\
\hline & & qR: TCCATTCAGAGTGTCACAAATACA \\
\hline \multirow[t]{2}{*}{ AtCAX1 } & NM_201901.3 & qF: AGTTGCGTTAGGCTCTGC \\
\hline & & qR: TTGATGTCCCAAGTGAATG \\
\hline \multirow[t]{2}{*}{ HVSL1251 } & AK371960.1 & qF: GGTCACAACCACGGCTATTT \\
\hline & & qR:GTCTTGAATGAGGGCAGAGC \\
\hline \multirow[t]{2}{*}{ AtALMT14 } & NM_001125913.1 & qF: CGGTAGACATAACCCCAACG \\
\hline & & qR: TCAACACCACAATCCTGCTC \\
\hline
\end{tabular}



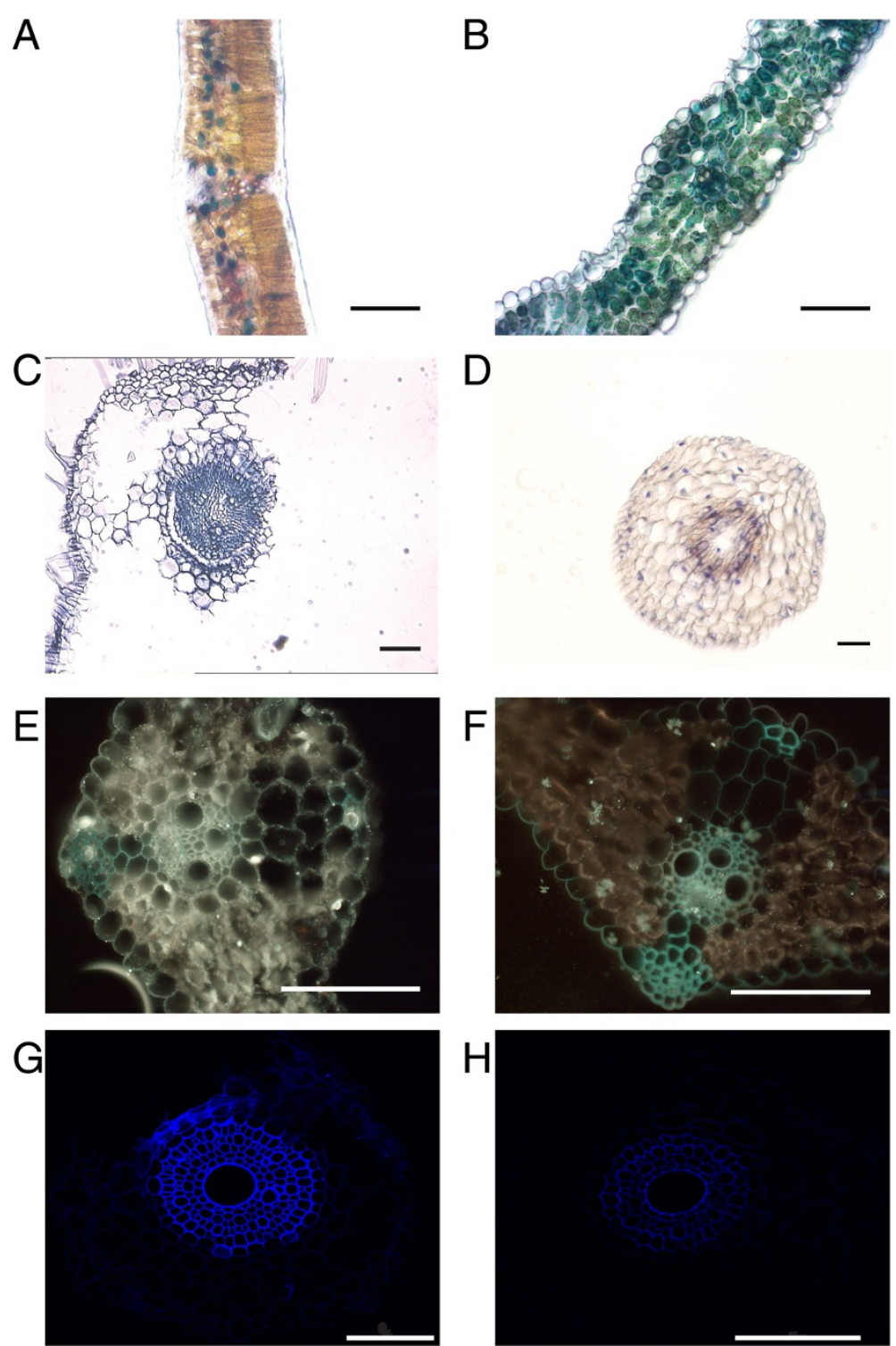

Figure 4 Examples of tissue sections where in situ PCR was unsuccessful. Inconsistent, non-uniform expression of 18S rRNA in Vitis vinifera leaf (A) and Hordeum vulgare leaf (B). Severely damaged Glycine max root cells (C). Distinct staining of cell nuclei (genomic DNA) in Triticum durum root section (D). Fluorescent staining using Elf97 in Hordeum vulgare leaf (E, Hv18S rRNA and $\mathbf{F}$, Hv18S rRNA negative control; Zeiss stereofluorescence microscope) and Triticum durum root sections (G, TmHKT1; 5-A and $\mathbf{H}$, TmHKT1;5-A negative control; Nikon confocal microscope). Please see Table 5 for troubleshooting tips. Scale bars represent $100 \mu \mathrm{m}$.

hands. For instance, when we used fluorescence to investigate the expression of TmHKT1;5-A in the + Nax2 NIL we detected a similar signal in our no RT negative control and our sample (Figure 4G and H); this contrasts with no signal in our no RT control using colourimetric detection (Figure 3D) or in the NIL -Nax2 (Figure 3A). Despite the lower signal of the autofluorescence we could not eliminate it using lower gain or spectral unmixing when using confocal microscopy. The use of fluorescence also has additional complications compared to the more reliable and straightforward colourimetric detection (such as cost of fluorescent substrates or primers, stability of fluorescent compounds and the cost and access to fluorescence/ confocal microscopes). Pesquet et al. [18] used fluorescence to detect in situ PCR products in plant tissues, however the protocol was not outlined and the technique has not been used very often; problems with autofluorescence interference when using fluorescent detection of in situ PCR products have since been noted [37].

\section{Conclusion}

We advocate the use of colourimetric detection of in situ PCR products for gene expression localization in plant tissue. Once the primers have been validated to be 
specific to the required target, this technique is a relatively quick and powerful tool to spatially define the expression profile of any gene of interest. We recommend the adoption of this technique as a standard method for the localization of genes in plant tissue.

\section{Competing interests}

The authors declare that they have no competing interest.

\section{Authors' contributions}

$M G, S K T$ and AA wrote the manuscript. RAB and SJC initiated the development of the in situ technique on plant tissue, GMM provided advice and training on microtomy, AA conducted most of the development (with CJ) and performed the wheat and soybean in situ PCR, CJ performed Arabidopsis CAX experiments, VMC performed and developed the technique for on-slide PCR, and performed the experiments on barley, epidermal peels and flowers. WWN performed additional experiments on barley. All authors commented on the manuscript.

\section{Acknowledgments}

This work was supported by Australian Research Council [DP130104205, FT130100709 and CE140100008 to MG, and DE120100307 to SKT] and a University of Adelaide, Faculty of Sciences equipment grant to SJC, RAB and MG.

\section{Author details}

${ }^{1}$ ARC Centre of Excellence in Plant Energy Biology, University of Adelaide, Glen Osmond, SA, Australia. ${ }^{2}$ ARC Centre of Excellence in Plant Energy Biology, The University of Western Australia, Perth, WA, Australia. ${ }^{3}$ Waite Research Institute \& School of Agriculture, Food and Wine, University of Adelaide, PMB1, Glen Osmond, SA 5064, Australia. ${ }^{4}$ Adelaide Microscopy Waite Facility, University of Adelaide, Glen Osmond, SA, Australia. ${ }^{5}$ ARC Centre of Excellence in Plant Cell Walls, University of Adelaide, Glen Osmond, SA, Australia. ${ }^{6}$ Centre for Cancer Biology, Division Immunology, Level 3, Frome Road, Adelaide, SA, Australia.

Received: 23 May 2014 Accepted: 10 September 2014 Published: 18 September 2014

\section{References}

1. Rhee SY, Mutwil M: Towards revealing the functions of all genes in plants. Trends Plant Sci 2014, 19:212-221.

2. Li S, Pandey S, Gookin TE, Zhao Z, Wilson L, Assmann SM: Gene-sharing networks reveal organizing principles of transcriptomes in Arabidopsis and other multicellular organisms. Plant Cell 2012, 24:1362-1378.

3. Chaumont F, Tyerman SD: Aquaporins: highly regulated channels controlling plant water relations. Plant Physiol 2014, 164:1600-1618.

4. Henderson S, Gilliham M: The 'gatekeeper' concept: cell-type specific molecular mechanisms of plant adaptation to abiotic stress. In Mechanisms of Plant Adaptation. Edited by Laitinen R. New Jersey: Wiley; 2015. in press.

5. Taylor CB: Promoter fusion analysis: an insufficient measure of gene expression. Plant Cell 1997, 9:273-275.

6. Conn SJ, Gilliham M, Athman A, Schreiber AW, Baumann U, Moller I, Cheng N-H, Stancombe MA, Hirschi KD, Webb AAR, Burton R, Kaiser BN, Tyerman SD, Leigh RA: Cell-specific vacuolar calcium storage mediated by CAX 1 regulates apoplastic calcium concentration, gas exchange, and plant productivity in Arabidopsis. Plant Cell 2011, 23:240-257.

7. Roy SJ, Conn SJ, Mayo GM, Athman A, Gilliham M: Transcriptomics on small samples. In Methods in Molecular Biology. Volume 913. Edited by Shabala S, Cuin TA. Humana Press: New Jersey; 2012:335-350.

8. Nuovo GJ: In situ localization of PCR-amplified DNA and CDNA. In Methods in Molecular Biology. Volume 123. Edited by Darby IA. New Jersey: Humana Press; 2000:217-238.

9. Birnbaum K, Jung JW, Wang JY, Lambert GM, Hirst JA, Galbraith DW, Benfey PN: Cell type-specific expression profiting in plants via cell sorting of protoplasts from fluorescent reporter lines. Nat Methods 2005, 2:615-619.

10. Brady SM, Orlando DA, Lee J-Y, Wang JY, Koch J, Dinneny JR, Mace D, Ohler U, Benfey PN: A high-resolution root spatiotemporal map reveals dominant expression patterns. Science 2007, 318:801-806.
11. Deal RB, Henikoff S: A simple method for gene expression and chromatin profiling of individual cell types within a tissue. Dev Cell 2010, 18:1030-1040.

12. Zhang C, Barthelson RA, Lambert GM, Galbraith DW: Global characterization of cell-specific gene expression through fluorescence-activated sorting of nuclei. Plant Physiol 2008, 147:30-40.

13. Grindberg RV, Yee-Greenbaum JL, McConnell MJ, Novotny M, O'Shaughnessy AL, Lambert GM, Arauzo-Bravo MJ, Lee J, Fishman M, Robbins GE, Lin X, Venepally P, Badger JH, Galbraith DW, Gage FH, Lasken RS: RNA-sequencing from single nuclei. Proc Natl Acad Sci U S A 2013, 110:19802-19807.

14. Ginart P, Raj A: RNA sequencing in situ. Nat Biotechnol 2014, 32:543-544.

15. Bagasra O: Protocols for the in situ PCR-amplification and detection of mRNA and DNA sequences. Nat Protoc 2007, 2:2782-2795.

16. Johansen B: In situ PCR on plant material with sub-cellular resolution. Ann Bot 1997, 80:697-700.

17. Koltai H, Bird DM: High throughput cellular localization of specific plant mRNAs by liquid-phase in situ reverse transcription-polymerase chain reaction of tissue sections. Plant Physiol 2000, 123:1203-1212.

18. Pesquet E, Barbier O, Ranocha P, Jauneau A, Goffner D: Multiple gene detection by in situ RT-PCR in isolated plant cells and tissues. Plant $J$ 2004, 39:947-959.

19. Lee $\mathrm{YH}$, Tegeder M: Selective expression of a novel high-affinity transport system for acidic and neutral amino acids in the tapetum cells of Arabidopsis flowers. Plant J 2004, 40:60-74.

20. Przybecki Z, Siedlecka E, Filipecki M, Urbanczyk-Wochniak E: In situ reverse transcription PCR on plant tissues. In Methods in Molecular Biology. Volume 334. Edited by Pellestor F. Humana Press: New Jersey; 2006:181-198.

21. Munns R, James RA, Xu B, Athman A, Conn SJ, Jordans C, Byrt CS, Hare RA, Tyerman SD, Tester M, Gilliham M: Wheat grain yield on saline soils is improved by an ancestral $\mathrm{Na}^{+}$transporter gene. Nat Biotechnol 2012, 30:360-U173.

22. Vandeleur RK, Sullivan W, Athman A, Jordans C, Gilliham M, Kaiser BN, Tyerman SD: Rapid shoot-to-root signalling regulates root hydraulic conductance via aquaporins. Plant Cell Environ 2014, 37(2):520-538.

23. Tiong J, McDonald GK, Genc Y, Pedas P, Hayes JE, Toubia J, Langridge P, Huang CY: HvZIP7 mediates zinc accumulation in barley (Hordeum vulgare) at moderately high zinc supply. New Phytol 2014, 201:131-143.

24. Byrt C, Xu B, Krishnan M, Lightfoot D, Athman A, Jacobs A, Watson-Haigh N, Munns R, Tester M, Gilliham M: The Na ${ }^{+}$transporter, TaHKT1;5-D, limits shoot $\mathrm{Na}^{+}$accumulation in bread wheat. Plant J 2014, doi:10.1111/ tpj.12651.

25. Conn SJ, Hocking B, Dayod M, Xu B, Athman A, Henderson S, Aukett L, Conn V, Shearer MK, Fuentes S, Tyerman SD, Gilliham M: Protocol: optimising hydroponic growth systems for nutritional and physiological analysis of Arabidopsis thaliana and other plants. Plant Methods 2013, 9:4.

26. Fox $\mathrm{CH}$, Johnson FB, Whiting J, Roller PP: Formaldehyde fixation. J Histochem Cytochem 1985, 33:845-853.

27. Thavarajah R, Mudimbaimannar VK, Elizabeth J, Rao UK, Ranganathan K: Chemical and physical basics of routine formaldehyde fixation. J Oral Maxillofac Pathol 2012, 16:400-405.

28. Dapson RW: Macromolecular changes caused by formalin fixation and antigen retrieval. Biotech Histochem 2007, 82:133-140.

29. Puchtler $\mathrm{H}$, Meloan $\mathrm{SN}$ : On the chemistry of formaldehyde fixation and its effects on immunohistochemical reactions. Histochemistry 1985, 82:201-204

30. Gilliham M, Athman A, Tyerman SD, Conn SJ: Cell-specific compartmentation of mineral nutrients is an essential mechanism for optimal plant productivity - another role for TPC1? Plant Signal Behav 2011, 6:1656-1661.

31. Ren ZH, Gao JP, Li LG, Cai XL, Huang W, Chao DY, Zhu MZ, Wang ZY, Luan S, Lin HX: A rice quantitative trait locus for salt tolerance encodes a sodium transporter. Nat Genet 2005, 37:1141-1146.

32. Sunarpi Horie T, Motoda J, Kubo M, Yang H, Yoda K, Horie R, Chan WY, Leung HY, Hattori K, Konomi M, Osumi M, Yamagami M, Schroeder Jl, Uozomi N: Enhanced salt tolerance mediated by AtHKT1 transporterinduced $\mathrm{Na}^{+}$unloading from xylem vessels to xylem parenchyma cells. Plant J 2005, 44:928-938.

33. Waters $\mathrm{S}$, Gilliham M, Hrmova M: Plant high-affinity potassium (HKT) transporters involved in salinity tolerance: structural insights to probe differences in ion selectivity. Int J Mol Sci 2013, 14:7660-7680. 
34. Gruber BD, Ryan PR, Richardson AE, Tyerman SD, Ramesh S, Hebb DM, Howitt SM, Delhaize E: HvALMT1 from barley is involved in the transport of organic anions. J Exp Bot 2010, 61:1455-1467.

35. Meyer S, Mumm P, Imes D, Endler A, Weder B, Al-Rasheid KAS, Geiger D, Marten I, Martinoia E, Hedrich R: AtALMT12 represents an R-type anion channel required for stomatal movement in Arabidopsis guard cells. Plant J 2010, 63:1054-1062.

36. De Angeli A, Zhang J, Meyer S, Martinoia E: AtALMT9 is a malate-activated vacuolar chloride channel required for stomatal opening in Arabidopsis. Nat Commun 2013, 4:1084.

37. Boubourakas IN, Voloudakis AE, Fasseas K, Resnick N, Koltai H, Kyriakopoulou PE: Cellular localization of peach latent mosaic viroid in peach sections by liquid phase in situ RT-PCR. Plant Pathol 2011, 60:468-473.

doi:10.1186/1746-4811-10-29

Cite this article as: Athman et al:: Protocol: a fast and simple in situ PCR method for localising gene expression in plant tissue. Plant Methods 2014 10:29.

\section{Submit your next manuscript to BioMed Central and take full advantage of:}

- Convenient online submission

- Thorough peer review

- No space constraints or color figure charges

- Immediate publication on acceptance

- Inclusion in PubMed, CAS, Scopus and Google Scholar

- Research which is freely available for redistribution 